\title{
Islamic Leadership, Work Motivation, and Employee Performance of Bank Jatim Syariah Surabaya
}

\author{
H Amaliyah ${ }^{1}$, A Fahrullah ${ }^{2}$ \\ ${ }^{1}$ Islamic Economics Study Program \\ ${ }^{2}$ Faculty of Economics, Universitas Negeri Surabaya \\ Email: hafidhotulamaliyah16081194032@mhs.unesa.ac.id
}

\begin{abstract}
This study aims to determine the positive and simultaneous influence between Islamic leadership and work motivation on the performance of employees of Bank Jatim Syariah Surabaya Branch Office. The research method used is quantitative with an associative approach. The selection of research subjects using the method probably sampling with simple random sampling is random sampling from the population. Data collection techniques using a questionnaire and measured with a Likert scale and then processed and analyzed with the IBM SPSS Statistics application. Based on the results of the analysis shows that Islamic leadership has a significant effect on performance, and work motivation also has a significant effect on employee performance, and Islamic leadership and work motivation simultaneously have a significant effect on employee performance. And the value of R. Square is equal to 0.480 so that means that the simultaneous influence between variable $\mathrm{X}$ with $\mathrm{Y}$ variable is $48 \%$.
\end{abstract}

Keywords: Islamic leadership, work motivation, employee performance

\section{INTRODUCTION}

In the era of globalization, Islamic banking in Indonesia has developed very rapidly. According to Otoritas Jasa Keuangan that banking assets in 2016 reached $5.55 \%$ and increased in 2017 to $5.78 \%$, although in 2018 it decreased from the previous year but the decline was not too significant, and in 2019 increased again reached 5.95\%. In addition, Islamic banking in Indonesia consists of Sharia commercial banks, Sharia business units, and Sharia people's financing banks. [1] Sharia business units are Sharia business units owned by conventional banking.

In Indonesia there are 20 Sharia business units, one of them is Bank Jatim Syariah which is a regional-owned business entity that strives to improve human resources because not only capital is the most important thing in a company, but also human resources are very important. Human resources are individual abilities whose abilities are needed by a company both knowledge, innovation and renewal for the company. [2]

The importance of increasing human resources so that employees can improve their performance. Own performance according to Bernard and Russel is the result of work that has been produced by workers within a predetermined period of time. [2] Basically, the performance itself is a quantity and quality produced by a worker, when he is given responsibility and can finish it as well as possible and in the Koran itself it has been explained that we must do it to the maximum extent so that Allah rejoices, it can be seen from QS Al-Qashash verse 77: 


$$
\begin{aligned}
& \text { وا بتغ فيماً ا تلك الله الد ار الأ خرة و لاتتس نصيبك من الد الد الدي }
\end{aligned}
$$

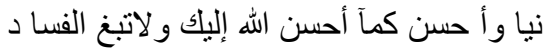

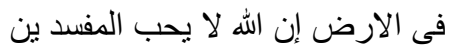

It means: "look for what Allah has bestowed upon you (happiness) of the afterlife, and do not forget your happiness (pleasure) worldly and do good (to others) as God has done good to you, and do not do damage in (face) earth. Surely Allah does not like those who do mischief."

From the above verse it has been explained that work is not only worldly activities but work also includes worship, which contains spiritual values with ukhrawi dimension, so that in work must be done seriously, expect God's pleasure, be responsible and be carried out earnestly, issue all abilities in order to get maximum results and God bless all the work we have done. [3]

Every employee must be responsible for his work, it was also explained by Mangkunegara that there are characteristics that must be owned by employees, one of which is that every employee must have a responsibility towards himself and be brave in taking risks, so employees have a purpose in life that is have realistic and have plans in working regularly and try to realize the work plan that has been made. Islamic leadership indicators can be measured through the quality of work, the quantity of work, work efficiency, professionalism, accuracy in completing work according to the specified time. Before doing this research. [4]

One of the factors that affect employee performance is the support of leaders, which means that support from leaders is very important for employees to be able to innovate, so leadership influence is very important so that employees can improve their performance. [4] A leader must be able to imitate the attributes of Rasullah Saw and eradicate mungkar (amar ma'ruf nahi mungkar). [3] Among the qualities of the first prophet to be imitated is shidiq which means to be honest, a leader must have honesty so that his employees can emulate it, then the second trait of the prophet to be imitated is trustful that means trustworthy, the third is tabligh which means a leader must be transparent and accountable, and the fourth is fathonah which means a leader must have the intelligence to lead his subordinates, in another sense a leader must also have extensive knowledge in order to continue to innovate and advance the company. Indicators of leadership can be measured through Shidiq, Amanah, Tabligh, Fathonah. At the Surabaya Jatim Bank Surabaya branch office has an Islamic leader that can be seen from the current leader is a Islamic Boarding School graduate, where many activities are carried out at the Surabaya branch of the East Java Syariah bank to get closer to God, some examples of activities are reading and writing the Koran carried out once a week, istighosah once a month at the end of the week end of the month and compensation to orphans. [3]

A leader must be able to influence his employees in order to improve their performance. Motivation itself is the desire of an employee to do the work. [4] Basically a company not only wants its employees to work skillfully and reliably but a company wants to make its employees work optimally, so that the employee will work hard, and get optimal results. A leader must have three conditions to be a leader, namely power, authority, and ability, so that the leader becomes trusted by its members. [5]

Motivation is considered very important to improve each individual employee to be willing to work hard and increase company productivity. In addition to improving employee performance motivation aims to improve employee morale and job satisfaction, then motivation also aims to increase employee loyalty to the company and improve employee discipline so employees do not often miss work. According to the theory of David MC. Clelland explained that humans have a reserve of energy that is motives, hopes, incentives that can be used when humans get motivated by someone. [6] The motive itself is the human driving force to work on, while hope is the opportunity given to achieve company goals, while intensive is an encouragement for employees by giving gifts 
when employees can work above the target. In this study work motivation indicators can be measured through motives, expectations and incentives.

One of the studies about the influence between work motivation and work environment on employee performance explains work motivation is an encouragement for employees to improve their performance, in this study work motivation and employee performance significantly influence. [7] Then this research is consistent with the research. [8] So that the higher the work motivation of employees, the higher the drive to be willing to put out their abilities at work.

A leader who has strong leadership will create an organizational management that encourages employee motivation and performance, which will encourage company productivity, and make the achievement of the vision and mission of an organization achieved. [6] Therefore Islamic leadership and work motivation are needed to improve employee performance. Then seen from this phenomenon, the authors are interested in conducting a study with the title "Islamic Leadership, Work Motivation, and Performance of Employees of Bank Jatim Syariah Surabaya”.

\section{METHOD}

In this study using quantitative research methods with an associative approach which means there is influence between one variable with another. This study uses a population of all employees at the Surabaya branch of the Syariah jatim bank in Surabaya, amounting to 50 employees and then using a sampling technique probably sampling. If the research will carry out multiple regression analysis then the number of sample members is at least 10 times the number of variables studied, the sample taken in this study is 3 variables multiplied by $10(3 \times 10=30)$ so that the samples in this study are numbered 30 employees. [9] Data collection techniques in the form of questionnaires that have been tested with validity and reliability testing. To test the hypothesis of this study using the $\mathrm{T}$ test, $\mathrm{F}$ test, determinant test $\left(\mathrm{R}^{2}\right)$.

\section{RESULT AND DISCUSSION}

\section{T test}

In this $\mathrm{T}$ test using IBM's SPSS statistics which aims to see the effect of each of the variables (X1) and variables (X2) on the $\mathrm{Y}$ variable. The following is a table of $\mathrm{T}$ test results:

Table 1. Coefficientsa

\begin{tabular}{cccccc}
\hline \multirow{2}{*}{ Model } & $\begin{array}{c}\text { Unstandartize } \\
\text { d Coefficients }\end{array}$ & \multicolumn{2}{c}{$\begin{array}{c}\text { Standardized } \\
\text { Coefficients }\end{array}$} & T & Sig. \\
\cline { 2 - 5 } & $\mathbf{B}$ & $\begin{array}{c}\text { Std. } \\
\text { Error }\end{array}$ & Beta & & \\
\hline (constant) & 2,969 & 7,247 & & 0.410 & .685 \\
\hline Islamic & 0.549 & .156 & 0.5 & 3,511 & 0.002 \\
leadership & & & 16 & & \\
\hline Work & 0.254 & .115 & 0.3 & 2,202 & 0.036 \\
motivation & & & 24 & & \\
\hline
\end{tabular}

Source: IBM SPSS Statistics and processed by the author

The table above explains that the significance value of $t$ is 0.05 and the value of $t$ table is 2.052. In the Islamic leadership variable the significance value is $0.002<0.05$ and the calculated $t$ value is $3.511>2.052$ so it can be concluded that the Islamic leadership variable has a partially significant effect on employee performance variables.

While the work motivation variable significance value of $0.036<0.05$ and $t$ count $2.202>2.052$ so it can be concluded that the work motivation variable has a significant effect on employee performance variable.

\section{F test}

The F test, which was carried out using IBM's SPSS statistics, aims to see the effect of the $\mathrm{X}$ variable on the $\mathrm{Y}$ variable. The following are the results of the $\mathrm{F}$ test:

\section{Table 2.Test Table F}

\begin{tabular}{lccccc}
\hline Model & $\begin{array}{c}\text { Sum of } \\
\text { Squares }\end{array}$ & Df & $\begin{array}{c}\text { Mean } \\
\text { Square }\end{array}$ & F & Sig. \\
\hline Regression & 139,105 & 2 & 69,553 & 12,456 & $0,000 \mathrm{~b}$ \\
\hline Residual & 150,549 & 27 & 5,584 & & \\
\hline Total & 0.254 & 29 & & & \\
\hline
\end{tabular}

Source: IBM SPSS Statistics and processed by the author

The table above explains the significance value $f$ of $0,000<0.05$ and it is known that $f$ count is 12.456> 3.35 so that it can be concluded that the Islamic leadership variable 
and work motivation simultaneously influence the employee performance variable.

\section{Determination Test $\left(R^{2}\right)$}

In the coefficient of determination test (R2) is used to see what percentage of influence is given by the variable $\mathrm{X}$ Variable $\mathrm{Y}$. after the determination coefficient test (R2) shows the value of $R$. Square which is equal to 0.480 so that means that the simultaneous influence between the variable $X$ (Islamic leadership and motivation work) with a Y variable of $48 \%$.

\section{Effect of Islamic Leadership on Employee Performance}

Based on the results of research conducted at the Bank Jatim Syariah Surabaya branch office using the $\mathrm{T}$ test shows that the Islamic leadership variable significantly influence employee performance variables. Rating Indicator Islamic leadership has namely Shidiq, Amanah, Tabligh, and fathonah. The Shidiq leader evaluation in question is the assessment of the leader in his observance of the religion and the leader's evaluation in prioritizing deliberation in making decisions, while the assessment of the leader of the Amanah is the assessment of the leader whether in deciding on a problem wisely, and creating organizational rules that are not burdensome and consistent with policies that are made it. Then for the assessment of leaders who are tabligh is the assessment of leaders in providing timely examples, praying in congregation, and working hard. As for the assessment of leaders who fathanah means the assessment of leaders whether professional in their fields and can organize well.

The head of the Surabaya Jatim Syariah Bank branch has implemented Islamic leadership based on the nature of Rasullah SAW (Shidiq, Amanah, Tabligh, Fatanah) based on the results of research conducted. This is in accordance with the word of Allah SWT in QS. An-Nisa verse 59 follows:

$$
\begin{aligned}
& \text { يا يها الذينء امنو أ طيعو الله وأ طيعو الرسول وأولى الامر }
\end{aligned}
$$

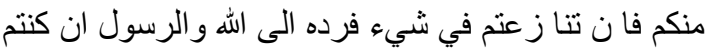

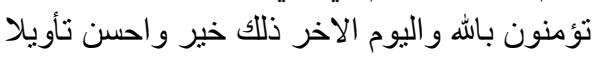

"O believers, obey Allah and obey Rasullah (Muhammad), and ulul amri among you. Then, if you have different opinions about something, then return it to Allah (Al-Quran) and Rasullah (As-Sunnah), if you believe in Allah and then later that is more important (for you) and better consequences."

By implementing Islamic leadership as taught by Rasulullah SAW to make leaders trusted by their members, when leaders are trusted by their members, employees will try to improve their performance. After the employee's performance increases, the company's economic productivity increases and will make the company compete with other banks in Indonesia and can make Sharia banking in Indonesia grow. With the development of Islamic banking in Indonesia, it can reduce the dependence of Muslims with conventional banking that uses interest as a reference, so as to avoid usury that is prohibited by Allah SWT.

The analysis of this research is in accordance with the research which shows that Islamic leadership has a significant effect on employee performance. [10] By increasing the confidence of employees in their leaders, making employees carry out the tasks given by the leader as best as possible, so that employee performance will increase and make the company's economic productivity increase and make the company can compete with other companies.

\section{Effect of Work Motivation on Employee Performance}

In research that has been done using the $\mathrm{T}$ test shows that work motivation has a significant effect on employee performance. Indicators of work motivation assessment are motives, expectations, and intensive according David MC.Lelland's Theory which explains that humans have energy reserves that are motives, hopes, incentives that can be used when humans get motivated by someone. [6] The application of work motivation at the Bank Jatim Syariah is to provide encouragement to employees in carrying out tasks properly and 
quickly, and free employees to take advantage of facilities that have been provided by the company, and strive to provide maximum results in order to get a good assessment from the leader and then increase their potential by participate in education and training programs, and provide bonuses for employees who have carried out the work exceeding the targets given.

Work motivation is given by the leader to the employees in order to encourage employees to work, in order to improve performance. This is in accordance with the word of Allah in the Surah Al 'Imron verse 14 below:

$$
\begin{aligned}
& \text { زين للناس حب الثهو ات من النسآء و البنين و القنطير } \\
& \text { الكقنطرة من الذهب والفضة و الخيل المسومة و الأنعم } \\
& \text { و الحرث ذللك متع الحيوةالدني و الله عنده حسن المئاب }
\end{aligned}
$$

"It is made to feel beautiful in the eyes of humans, love of what is desired, in the form of women, children, wealth of many types of gold, silver, choice horses, livestock, and rice fields. That is the pleasure of life on earth, and in Allah's place is a good return (heaven). "

The leader of Surabaya Jatim Syariah Bank gave motivation to his employees because of this so that Muslim employees are motivated to work and achieve company goals. When employees are motivated and improve their performance, the company's economic productivity increases so that companies can compete with other companies and develop Islamic banking in Indonesia. With the development of Sharia banking in Indonesia, it can make people believe in Sharia banking, then Sharia banking can raise public funds and channel them back to the public in the form of financing in accordance with Sharia principles.

In this study work motivation has a significant effect on employee performance, so this study is consistent with research which shows that work motivation has a significant effect on employee performance. [11-12] Based on the theory this study has a conformity theory that work motivation is an encouragement to influence people in their work.[5] With the encouragement to work will make employees work optimally and achieve the targets that have been given by leaders, thus making employee performance increase and increase the company's economic productivity.

6. Effect of Islamic Leadership and Work Motivation on Financial Performance

Based on the results of the $\mathrm{F}$ test that has been done explain that Islamic leadership and work motivation simultaneously influence and based on the coefficient of determination (R2) test simultaneous effect of $48 \%$. Indicators of performance appraisal in this study areassessment of work quality, work quantity, work efficiency, professionalism and timeliness. The quality of work in question is the assessment of employees in completing the work provided as well as possible, and carry it according to the direction of the leader, while the intended evaluation of work quantity is the assessment of employees in completing tasks according to the specified targets and the assessment of delivering work to superiors continuously, for the assessment of work efficiency in question is an assessment of employees in completing work in accordance with the scale of priorities and observance of compliance with applicable work regulations. In the professional assessment of the work referred to is the assessment of employees in understanding and carrying out tasks in accordance with their responsibilities and assessments in adhering to existing SOPs,

The performance of employees of Bank Jatim Syariah can improve due to several factors, one of which is Islamic leadership and work motivation, by increasing the performance of the employees it can increase the company's economic productivity and make the company competitive with other companies and can develop Islamic banking in Indonesia. So that the development of Islamic banking can make people avoid usury and gharar, and can stabilize the monetary economy to be maintained, because Islamic banking can reduce economic warming caused by inflation, to avoid competition between unhealthy financial institutions. 
After an analysis of this research shows the similarity of the results of research that has been done which shows that Islamic leadership and work motivation have a significant effect on employee performance. [13-14] From the results of the study there is a theoretical suitability that leadership and work motivation are among the factors that influence employee performance. Leadership is an organizational factor and motivation is a psychological factor needed by employees in improving their performance. [15] By increasing employee performance, it can increase the company's economic productivity.

\section{CONCLUSION}

Based on the results of research conducted, it can be concluded that Islamic leadership has a significant effect on employee performance, and work motivation has a significant effect on employee performance. And Islamic leadership and work motivation simultaneously have a significant effect on the performance of employees of Bank Jatim Syariah Surabaya Branch Office.

Suggestions for Bank Jatim Syariah Surabaya Branch Office to improve Islamic leadership by implementing Islamic leadership such as the characteristics that Rasullah SAW has exemplified and motivating employees by providing intensive and bonuses if employees can work towards targets, so that employee performance can improve and can improve company productivity. It is also hoped that further researchers will be able to examine different research objects that are already known to the public such as companies or institutions that are trusted as a comparison and can be used as general conclusions.

\section{REFERENCES}

[1] OJK. (2019, March 26). sharia-bankingstatistics. Picked December 1, 2019, from the Financial Services Authority: www.ojk.go.id

[2] Priansa, DJ , Staffing Performance Management. Bandung: CV Library Loyal, (2017).
[3] Nuryadin, D., Tohirin, \& Ilhamdi, Modern Organizational Behavior is Complemented by the Islamic Perspective. Jakarta: media discourse partners, 2019.

[4] Bintoro, \& Daryanto, Employee Performance Appraisal Management, Yogyakarta: Gava Media Publisher, 2017.

[5] Murtado, D., Suhayati, I., \& Zoharudin, U, Management of the Perspectives of the Qur'an and Hadith. Bandung: PUBLIC YRAMA WIDYA, 2019.

[6] Hasibuan, MS, Organization and Motivation. Jakarta: offset graphic rays, 2014.

[7] Gardjito, AH, Musadieq, MA, \& Nurtjahjono, GE, The Effect of Work Motivation and Work Environment on Employee Performance. Journal of Business Administration, 1-8, 2014.

[8] Abusama, M., Haming, M., Hamzah, MN, \& Ramlawati, Effect of motivation, competence and Islamic leadership on job satisfaction and Teacher performance in vocational high school. IOSR Journal of Business and Management (IOSR-JBM), 1-12, 2017.

[9] Sugiyono, Quantitative Research Methods. Bandung: CV. ALFABETA, 2018.

[10] Harahap, S., The Effect of Islamic Leadership and Work Motivation on Employee Performance at PT. Bank Syariah Mandiri, Tbk. Human Falah, 253-270, 2016.

[11] Prabowo, TS, Noermijati, \& Irwanto, DW, The Influence of Transformational Leadership and Work Motivation on Employee Performance Mediated by Job Satisfaction. HOUR, 171- 178, 2018.

[12] Bhatti, OK, Aslam, US, Hassan, A., \& Sulaiman, M., Employee motivation an Islamic perspective. Humanomics, 33-47, 2019.

[13] Fahrullah, A., Effect of Islamic Leadership on Work motivation and employee performance and employee welfare. al-Uqud: Journal of Islamic Economics, 121-140, 2018.

[14] Putra, R., The Effect of Leadership and Work Motivation on Employee Performance of PT. Bank Syariah Mandiri, Tbk Petisah Medan Branch. USU Journal, 103-129, 2018.

[15] Sule, ET, \& Saefullah, K., introduction to management. Jakarta: Prenada Media Group, 2015. 